\title{
An Assessment of the Trade Effects of the East African Community Customs Union on Member Countries
}

\author{
Steven Buigut \\ Correspondence: Steven Buigut, School of Business Administration, American University in Dubai, P.O. Box \\ 28282, Dubai, UAE. Tel: 971-4-318-3117. E-mail: sbuigut@aud.edu
}

Received: August 1, 2012

Accepted: August 20, $2012 \quad$ Online Published: September 5, 2012

doi:10.5539/ijef.v4n10p41

URL: http://dx.doi.org/10.5539/ijef.v4n10p41

\begin{abstract}
This study uses a modified gravity model to estimate the trade effects of the recently implemented East African Community (EAC) customs union on individual member countries. The analysis is based on bilateral import data for seventy potential trading partners for the EAC bloc. It covers the period 1996 to 2009. The results suggest the customs union has generated disproportionate impacts on intra bloc exports and imports for individual member countries. Kenya, Uganda and Rwanda have seen a significant increase in their intra EAC exports, while Kenya and Tanzania have seen a significant increase in their intra EAC imports. Significant changes are seen in Kenyan exports and Tanzanian imports up to three years prior to the actual implementation.
\end{abstract}

Keywords: trade effect, customs union, gravity model, East African Community

JEL Classification Code: F13, F15

\section{Introduction}

The EAC integration effort started with the signing of the "Agreement for the Establishment of the Permanent Tripartite Commission for East African Co-operation" in 1993 by Kenya, Uganda and Tanzania. This effort by the three East African countries revived a regional bloc that had failed earlier in 1977. The East African Community (EAC) has since then advanced its integration agenda rapidly. The three members (Kenya, Uganda, and Tanzania) signed a customs union treaty in 2004. This was implemented over a transitional period of five years. The asymmetric internal tariff elimination structure agreed upon granted Ugandan and Tanzanian goods into Kenya immediate duty free status. Goods flowing between Uganda and Tanzania and some Kenyan goods (category A) into Uganda and Tanzania also achieved duty free status immediately. However the internal tariff on some Kenyan goods (category B) to Uganda and Tanzania was reduced gradually from $10 \%$ to $0 \%$ over the five year period. Rwanda and Burundi joined the EAC in 2007 bringing the EAC membership to five. The EAC members have signed a common market protocol in 2009. The operationalization of the common market started in 2010. The EAC started negotiating a protocol to establish the East African Monetary Union (EAMU) in January 2011.

As the EAC integration deepens, it is a pertinent question for policy makers to ask what effect, if any, this has had on the region's trade flows. To show such effects one needs to establish a counterfactual of trade that would have occurred in the absence of the agreement (Clausing, 2001). The gravity model has been used frequently to predict the bilateral trade in the absence of any agreement with the effects of the trade agreements measured by a regional free trade agreement (FTA) dummy (Magee, 2008). A similar approach is frequently used to assess the effect of currency unions on trade (see for example Glick and Rose 2002; Rose and Van Wincoop, 2001). Care must be exercised in the use of the gravity model with dummies capturing the treatment effect. It has been established that countries select endogenously into Free Trade Agreements (FTAs) for a host of reasons that may include historical, cultural, and other unobservable reasons that are likely correlated to level of trade. For example, Magee (2003) shows empirically that higher bilateral trade flows increase the likelihood that countries will form FTAs.

Bair and Bergstrand (2007) also provide empirical support for the claim that the typically used cross section FTA coefficients are biased. The source of potential bias is omitted variables. In their study of the determinants of FTAs, they find strong evidence that countries that have FTAs tend to share economic characteristics that should enhance net economic welfare gains from an FTA, such as the size and similarity of their GDPs, closeness to each other, and the remoteness from the rest of the world. These variables also tend to explain a large amount of trade flows between countries. Hence FTA dummies are not exogenous random variables. To overcome these problems, a 
number of studies (e.g. Magee, 2008; Carrere, 2006; Egger and Pfaffermayr, 2003) suggest including country pair fixed effects to control for historical and time-constant factors that affect the level of trade between partner countries. Several studies suggest preference of fixed effects model over random effects model (e.g. Egger, 2000).

The majority of existing ex post studies estimate average treatment effect of an FTA for all its members. This presumes the effect of the FTA is similar for all the members. However it is not always true that membership in an FTA would necessarily produce the same effect on trade flows for all the member countries. It is reasonable to expect that in cases where countries have some structural differences, a larger than proportionate effect may accrue to more competitive members. Such differences may be large enough to warrant specific country analysis. This is a very relevant issue for the EAC given one of the main concerns that led to the demise of the original EAC in 1977, in addition to ideological and political differences at the time, was the concern that some members were benefiting more than others (Goldstein and Ndungu, 2001). Some of these problems still exist today and regional integration should be pursued without losing sight of the problems that led to the collapse of the earlier EAC (ibid). However after the revival of the EAC there have been no corresponding empirical studies to assess the specific effects on trade among the member states arising from the EAC integration process. This study attempts to fill this gap. The main objective of this study therefore is to estimate the effects of the customs union agreement on each of the EAC members' trade flows. Some researchers (e.g. Frankel, 1997) argue there is a tendency for trade flows to be affected in advance of implementation in anticipation of the actual implementation. Another objective of the present study is to investigate the time frame of such effects, if this happened on implementation or before. The customs union was signed in 2004, and gradually implemented since 2005. The empirical estimation is carried out using a gravity model that controls for country and time effects.

There are currently very few studies that focus on the EAC integration process. One study that attempts to capture the effect of the EAC integration effort on specific countries is Darku (2009), who studies the effect of EU and EAC on Tanzania for the period 1980 - 2004. He finds moderate trade creation effects on Tanzania's bilateral trade. Thus this study does not capture the EAC's customs union implementation period which happened from 2005 , but considers only the earlier integration effort preceding the customs union. It also analyzes one EAC member. The present study estimates the effect on each of the five members of the EAC. Musila (2005) also uses a gravity model to study the Common Market for Eastern and Southern Africa (COMESA), Economic Community of Central African States (ECCAS) and Economic Community of West African States (ECOWAS) for the period 1991-98. His findings indicate some trade creation effects from COMESA and ECOWAS but not ECCAS. Aside from the difference in the period of analysis, this study does not specifically analyze the EAC. Likewise Sawkut (2006) uses a standard gravity model augmented with three dummy variables to capture the effects of COMESA. The time period of the analysis is from 1980-2001. So it mostly captures the preferential trade area (PTA) for Eastern and Southern Africa, the forerunner of COMESA and COMESA before FTA.

There are currently no empirical studies that have focused on estimating specific trade effects of the custom union on each of the five EAC members. This study is the first comprehensive analysis of the effects of the EAC customs union on the trade flows for each individual member country. The rest of the paper is organized as follows. Section 2 presents the data used, while Section 3 describes the empirical models. In Section 4 the results are discussed and concluding remarks provided in Section 5.

\section{Data Sources}

Bilateral import data was obtained from the International Monetary Fund's (IMF's) Direction of Trade Statistics (DOTs) CD in US dollars (January 2011). This is converted to real imports using US consumer price index. The period considered is for the years $1996-2009$ for a total of seventy potential trading partners for the EAC countries. The EAC partner countries included cover Africa, Western Europe, Eastern Europe, North and South America (see Appendix I for the list of the countries). With 70 trading partners and 14 years there are 980 bilateral data points for each EAC country analyzed.

The key control variables are the Real GDP sourced from the World Bank's World Development Indicators CD (2011). The population figures are obtained from the IMF's International Financial Statistics (IFS) CD (August 2011). The real exchange rates are computed from nominal exchange rate and consumer price index sourced from the IFS CD. These are given as country i's currency (importer country) per country j's (exporter country) currency, that is importer country currency per unit of exporter country currency. Other variables that may influence trade flows such as the distances between the trade partners, and similarity in languages, are sourced from the Institute for Research on the International Economy (CEPII) data base (dist_cepii.xls file).

\section{Empirical Model}

The gravity model has become the favored tool to assess ex-post trade creation and trade diversion effects of 
regional trade agreements. A typical gravity model often used is of the form:

$$
\begin{aligned}
& \ln \left\lfloor M_{i j t}\right\rfloor=\alpha_{0}+\beta_{1} \ln \left\lfloor D_{i j}\right\rfloor+\beta_{2} \ln \left[Y_{i t}\right]+\beta_{3} \ln \left\lfloor Y_{j t}\right\rfloor+\beta_{4} \ln \left[R E R_{i j t}\right]+\beta_{5} R T A_{-} \text {int } r a_{i j t} \\
& +\beta_{6} R T A_{-} \text {imports } s_{i j t}+\alpha X_{i j t}+\varepsilon_{i j t}
\end{aligned}
$$

where $M_{i j}$ is the imports of country i from country $j . D_{i j}$ is the distance between the two countries, $Y_{i t}$ and $Y_{j t}$, the real GDPs of countries $\mathrm{i}$ and $\mathrm{j}$, RER is the real exchange. $R T A_{-}$int $r a_{i j t}$ is a dummy variable which is $=1$ if both partners $i$ and $j$ belong to the FTA, zero otherwise. This captures intra-bloc trade. RTA_imports $s_{i j t}$ is $=1$ if importing country $i$ belongs to the customs union and exporting country $\mathrm{j}$ to rest of world, zero otherwise. This captures the effect on bloc imports from the rest of world. $X_{\mathrm{ijt}}$ is a vector of other characteristics, e.g. use of common language, colonial ties, contiguity etc., that may have an effect on bilateral trade.

However, a long list of studies (Carrère, 2006; Bair and Bergstrand, 2007; Egger and Pfaffermayr, 2003; Magee, 2008) have suggest estimates from this formulation may be biased. There is strong evidence that countries that have FTAs tend to share economic characteristics that should enhance net economic welfare gains from an FTA. Hence trade dummies are not exogenous. To deal with this problem, models that include country pair fixed effects have been suggested (see Magee 2008; Carrere, 2008).

$$
\begin{aligned}
& \ln \left\lfloor M_{i j t}\right\rfloor=\alpha_{i j}+\alpha_{t}+\beta_{1} \ln \left\lfloor D_{i j}\right\rfloor+\beta_{2} \ln \left[Y_{i t}\right]+\beta_{3} \ln \left\lfloor Y_{j t}\right\rfloor+\beta_{4} \ln \left[R E R_{i j t}\right]+\beta_{5} R T A_{-} \operatorname{int} r a_{i j t} \\
& +\beta_{6} R T A_{-} \text {imports }_{i j t}+\alpha X_{i j t}+\varepsilon_{i j t}
\end{aligned}
$$

where $\alpha_{i j}$ are the specific effects associated with each bilateral trade flow such that $\alpha_{i j} \neq \alpha_{j i}, \alpha_{t}$ are the specific effects associated with time effects. The rest of the variables are as discussed earlier under Equation 1. The bilateral effects account for any time invariant geographical, historical, political and other bilateral influences which lead to deviations from a country pair's normal propensity to trade (Egger and Pfaffermayr, 2003; Magee, 2008).

The aim of the present study is to identify the effects of a regional trade agreement, the EAC customs union, on trade flows for individual member countries. To achieve this objective, the study uses a modified version of the gravity model in Equation 2. The first approach analyzes the effect of the EAC customs union on exports for each of EAC member countries. In Equation 3 only importer country fixed effects is included while in Equation 4 importer country and time fixed effects are included.

$$
\begin{aligned}
& \left.\ln \left\lfloor M_{i j t}\right\rfloor=\alpha_{0}+\alpha_{i}+\beta_{1} \ln \left[D_{i j}\right\rfloor+\beta_{2} \ln \left[Y_{i t}\right]+\beta_{3} \ln \mid Y_{j t}\right\rfloor+\beta_{4} R E R_{i j t}+ \\
& \beta_{5} C U A_{-} \text {int } r a_{i j t}+\alpha X_{i j t}+\varepsilon_{i j t}
\end{aligned}
$$

where $\mathrm{M}_{\mathrm{ij}}$ are the imports of country i from country j. $\quad \alpha_{0}$ is a constant, $\alpha_{i}$ are the importer country effects. Note that since the exporter, $\mathrm{j}$, is restricted to one EAC member at a time, country pair fixed effects, $\alpha_{i j}$, basically reduces to $\alpha_{i}$. The ex-post assessment of the trade agreement, the customs union agreement (CUA) in this case, on the volume of trade will include a dummy variable, CUA_intra which is $=1$ if both partners $i$ and exporter country $\mathrm{j}$ belong to the EAC customs union, zero otherwise. This captures how exports to EAC members have changed for the specific EAC member country, $\mathrm{j}$, in question. The dummy variable, CUA_intra, used to capture the customs union is constructed based on the date of implementation (the year 2005) for Kenya, Uganda and Tanzania and the date of entry (the year 2007) for Burundi and Rwanda. A positive and significant coefficient means intra-bloc exports for the member country have increased.

In Equation 4 the time fixed effects are included.

$$
\begin{aligned}
& \ln \left\lfloor M_{i j t}\right\rfloor=\alpha_{0}+\alpha_{i}+\alpha_{t}+\beta_{1} \ln \left\lfloor D_{i j}\right\rfloor+\beta_{2} \ln \left[Y_{i t}\right]+\beta_{3} \ln \left\lfloor Y_{j t}\right\rfloor+\beta_{4} R E R_{i j t}+ \\
& \beta_{5} C U A_{-} \text {int } r a_{i j t}+\alpha X_{i j t}+\varepsilon_{i j t}
\end{aligned}
$$

where $\alpha_{t}$ is the time fixed effects, everything else same as in Equation 3. $\alpha_{i}+\alpha_{t}$ in Equation 4 can actually be considered as similar to $\alpha_{i j}+\alpha_{t}$ in (2) with $\mathrm{j}$ restricted to one country at a time. Note that since the analysis uses only exports by one country to 70 trading partners it is only possible to capture exports within the block or outside the bloc, not both. The total change in exports for a given country for time $\mathrm{t}$ can be split into two parts; change in intra EAC exports and change in exports outside the EAC. Thus both cannot be captured at the same time. Thus CUA_intra captures intra EAC exports in this specification. 
In the second approach the effects of the customs union on the imports of the EAC member countries are analyzed. In Equation 5 exporter country fixed effects is included while in (6) both exporter country and time fixed effects are included.

$$
\begin{aligned}
& \ln \left\lfloor M_{i j t}\right\rfloor=\alpha_{0}+\alpha_{j}+\beta_{1} \ln \left\lfloor D_{i j}\right\rfloor+\beta_{2} \ln \left[Y_{i t}\right]+\beta_{3} \ln \left\lfloor Y_{j t}\right\rfloor+\beta_{4} R E R_{i j t}+ \\
& \beta_{5} C U A_{-} \text {int } r a_{i j t}+\alpha X_{i j t}+\varepsilon_{i j t}
\end{aligned}
$$

$\alpha_{j}$ are the exporter country effects. Note that since the importer country, i, is constrained to one EAC member at a time, importer country effect, $\alpha_{i}$, is constant. Thus the country pair fixed effect $\alpha_{i j}$ actually reduces to exporter country effects, $\alpha_{j}$, since i is one country.

The ex-post assessment of the customs union agreement (CUA), on the volume of trade uses a dummy variable, CUA_intra which is $=1$ if both importer country $\mathrm{i}$ and partners $\mathrm{j}$ belong to the EAC customs union, zero otherwise. This captures intra-bloc trade, how imports from EAC members have changed for the specific EAC member country, i, in question. A positive and significant coefficient means intra -bloc imports for the member country have increased.

In Equation 6 time fixed effects are included.

$$
\begin{aligned}
& \left.\left.\left.\ln \mid M_{i j t}\right\rfloor=\alpha_{0}+\alpha_{j}+\alpha_{t}+\beta_{1} \ln \mid D_{i j}\right\rfloor+\beta_{2} \ln \left[Y_{i t}\right]+\beta_{3} \ln \mid Y_{j t}\right\rfloor+\beta_{4} R E R_{i j t}+ \\
& \beta_{5} C U A_{-} \text {int } r a_{i j t}+\alpha X_{i j t}+\varepsilon_{i j t}
\end{aligned}
$$

$\alpha_{j}+\alpha_{t}$ is actually similar to using $\alpha_{i j}+\alpha_{t}$ with i constrained to one member country at a time. In that case $\alpha_{i j}$, reduces to $\alpha_{j}$. Note that since the analysis uses only imports by one country from 70 trading partners it is only possible to capture imports from within the block or from outside the bloc, not both. The total change in imports for a given country for time $t$ can be split into two parts; change in intra EAC imports and change in imports from outside the EAC. Thus both cannot be captured at the same time. Thus CUA_intra captures intra EAC imports in this specification.

\section{Results}

This section discusses the estimation results. Figure 1 shows the real total value (in US \$) of intra-EAC imports over time for each of the five EAC member countries (Kenya, Tanzania, Uganda, Burundi and Rwanda). The intra-bloc imports have largely been increasing from 2000/2001. Uganda has generally imported more from the EAC than the other countries, though Tanzania's imports from the regional bloc have caught up over the last few years. However the growth of Uganda's imports has been low and erratic. Tanzania's imports have increased substantially from around $\$ 100$ million in 2002 to over $\$ 400$ million in 2007 . This sharp growth predates the actual customs union implementation by a few years. The same case applies to Rwanda, whose imports have increased from around $\$ 60$ million to over $\$ 300$ million. This growth also predates the customs union implementation. Note that Rwanda officially joined the union in 2007. Kenya has traditionally imported little from the EAC members. However her imports have increased sharply from around $\$ 55$ million in 2004 to $\$ 300$ million by 2009. Unlike Tanzania and Rwanda this increase seems to come immediately with the implementation of the customs union. Burundi's imports have increased but only marginally from 2001. It does not show any changes upon entry in 2007, but rather seems to be leveling off. 


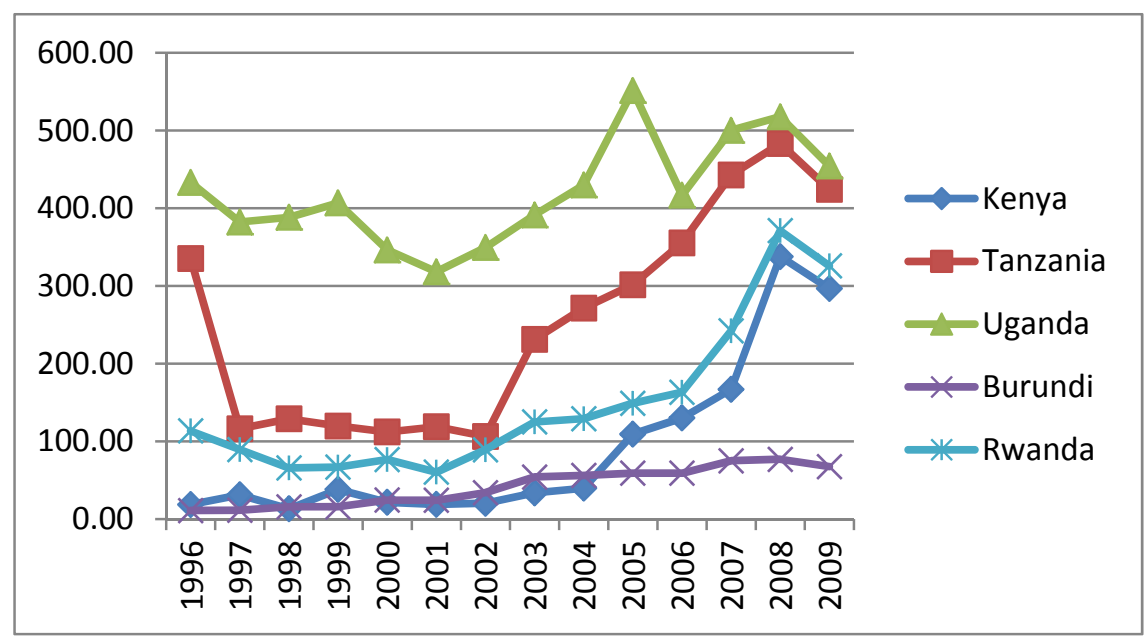

Figure 1. Volume of Intra EAC Imports by Member Countries (Millions US \$), 1996-2009

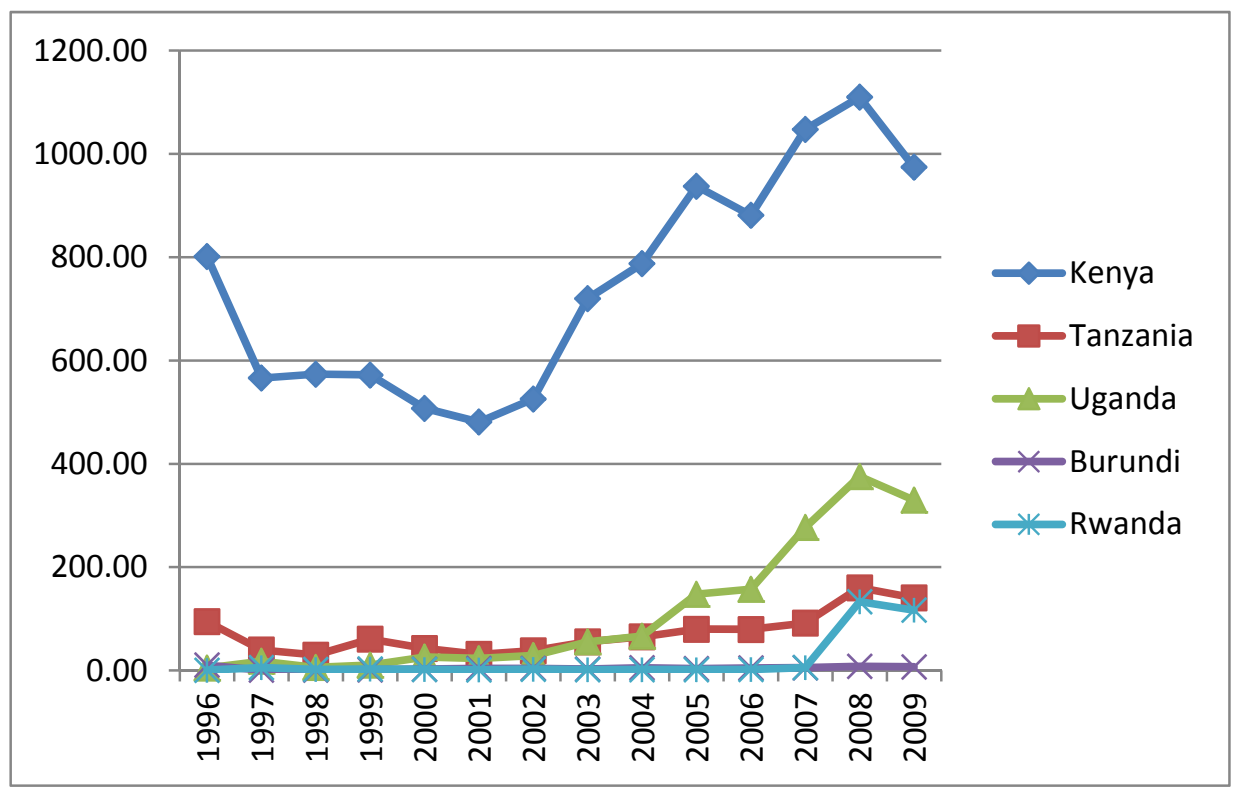

Figure 2. Volume of Intra EAC Exports by Member Countries (Millions US \$), 1996-2009

Figure 2 shows the intra-EAC exports over time for each of the EAC member countries. The figure suggests there has been a sharp growth of Ugandan exports to other EAC member countries, from a low of around $\$ 65$ million in 2004 to around $\$ 330$ million by 2009. Kenya's exports have increased but the increase predates the implementation of the customs union. Thus Kenya's export trends seem to suggest some anticipation effect. Tanzania's exports show only a marginal increase. There is a slight pump in exports from Rwanda to the EAC bloc upon entry in 2007. Burundi's exports show no sign of increasing over the period of analysis.

Regression results are discussed next. The first EAC member country considered is Kenya in Table 1. Table 1 shows the estimation results of customs union effect on Kenya's intra-EAC trade flow. In model 1, the dependent variable is the natural log of real imports (ln real imports) from Kenya (i.e. exports by Kenya), while it is the exports from Kenya in model 2. 
Table 1. Effect of the EAC Customs Union on Kenya's Intra EAC Trade

\begin{tabular}{lllll}
\hline & $\begin{array}{l}\text { Model } 1^{\mathrm{A}} \\
(\text { Equation 3) }\end{array}$ & $\begin{array}{l}\text { Model 1 } \\
\text { (Equation 4) }\end{array}$ & $\begin{array}{l}\text { Model 2 } \\
\text { (Equation 5) }\end{array}$ & $\begin{array}{l}\text { Model 2 } \\
\text { (Equation 6) }\end{array}$ \\
\hline $\begin{array}{l}\text { Dependent } \\
\text { variable: } \\
\ln (\text { imports) }\end{array}$ & $\begin{array}{l}\text { Dependent } \\
\text { variable: } \\
\text { ln(imports) }\end{array}$ & $\begin{array}{l}\text { Dependent } \\
\text { variable: } \\
\text { ln(exports) }\end{array}$ & $\begin{array}{l}\text { Dependent } \\
\text { variable: } \\
\text { ln(exports) }\end{array}$ \\
\hline Explanatory variables & Coefficient & Coefficient & Coefficient & Coefficient \\
\hline Contiguity & 1.509 & 1.507 & 5.407 & 5.353 \\
& $(0.64)$ & $(0.64)$ & $(* 1.87)$ & $(* 1.85)$ \\
\hline Common language - & 1.561 & 1.481 & 2.367 & 2.385 \\
ethnology & $(0.46)$ & $(0.64)$ & $(* * 2.22)$ & $(* * 2.22)$ \\
\hline Distance & 1.092 & -0.990 & 0.214 & 0.196 \\
& $(* *-2.35)$ & $(* *-2.12)$ & $(0.42)$ & $(0.38)$ \\
\hline Population - importer & 0.471 & 0.477 & -2.024 & - \\
& $(0.76)$ & $(0.77)$ & $(-1.25)$ & \\
\hline Population - exporter & -1.050 & -- & -0.932 & -0.924 \\
& $(-0.89)$ & & $(-1.14)$ & $(-1.13)$ \\
\hline Real GDP - importer & -0.084 & -0.159 & 0.817 & -- \\
& $(-0.26)$ & $(-0.49)$ & $(0.70)$ & \\
\hline Real GDP - exporter & 0.207 & -- & 0.648 & 0.641 \\
& $(0.25)$ & & $(1.39)$ & $(1.37)$ \\
\hline Real exchange rate & 0.020 & 0.028 & 0.074 & 0.080 \\
& $(0.50)$ & $(0.69)$ & $(1.33)$ & $(1.42)$ \\
\hline CUA_intra & -0.077 & -0.085 & 0.712 & 0.738 \\
& $(-0.30)$ & $(-0.34)$ & $(* 1.95)$ & $(* * 2.01)$ \\
\hline Constant & 5.130 & 7.347 & -35.077 & -22.670 \\
& $(0.31)$ & $(1.20)$ & $(-1.61)$ & $(* * *-2.99)$ \\
\hline
\end{tabular}

Notes: Model 1 estimates effect on Kenya's exports to the EAC countries (i.e. imports from Kenya); Model 2 estimates effect on Kenya's imports from EAC countries (i.e. exports to Kenya). ${ }^{\text {A) }}$ Includes country fixed effects only; ${ }^{\text {B) }}$ includes both country and time fixed effects. The t-statistics are provided in brackets; $\left({ }^{* *}\right),\left({ }^{*}\right),\left({ }^{*}\right)$ indicates the coefficients are statistically significant at the $1 \%, 5 \%$, or $10 \%$ level. $(--)$ indicates variable gets dropped. The analysis uses only exports (imports) by one country to (from) 70 trading partners with time fixed effects controlling for change in this variable in time $t$ which means this variable cannot be estimated.

Column one shows the results from estimating Equation 3 in the text. This captures Kenya's exports to EAC member countries when only country fixed effects are included. Column two shows estimation results from Equation 4. This captures Kenya's exports to EAC countries when both country and time fixed effects are included. The key variable of interest is CUA-intra, which is a dummy variable to capture the effect of the customs union as explained in section 3. Both results (columns one and two) suggest the customs union implementation has not had a significant contemporaneous effect on Kenya's intra-EAC exports. This could be mainly due to the higher share of Kenyan exports in the EAC. However, note that a large share of the increase occurs prior to the customs union implementation in 2005 - probably in anticipation of the event. This anticipatory effect is not captured in the regression estimation. This effect is shown in results given in Table 6 . Column three shows the results from estimating Equation 5 in the text. This captures Kenya's imports from the EAC member countries when only country fixed effects are included. Column four shows estimation results from Equation 6 which captures Kenya's imports from the EAC countries when both country and time fixed effects are included. Again looking at the key variable of interest, CUA-intra, both results (columns three and four) suggest the customs union has had a significant positive effect on Kenya's intra-bloc imports.

Both coefficients are positive $(0.712$, and 0.738$)$ and significant at $10 \%$ and $5 \%$ level respectively. Hence the customs union effect is given by $[100 *(\mathrm{e} 0.712-1)=103.8 \%]$. This suggests the customs raised intra-bloc trade level by 104 percent (roughly double). Figure 1 suggests a five-fold increase from $\$ 60$ million to over $\$ 300$ million, which lends support to the results shown in Table 1. For all the results that follow this specification distinction used in Table 1 is maintained: Model 1A (column 1) and 1B (column 2) analyze exports. Model 2A (column 3) and 2B (column 4) analyze imports. Specification A includes country fixed effects, while B includes both country and time fixed effects. 
Table 2 shows the estimation results of the customs union effect on Tanzania's intra-EAC trade. The dependent variable is the natural $\log$ of real imports (ln real imports), and column one through four indicate the specifications as discussed for Table 1. Columns one and two estimation results suggest the customs union has not had a significant effect on Tanzania's exports to the EAC. Columns three and four results also suggest the customs union has not had any significant effect on Tanzania's imports from the EAC countries. This is contrary to what is suggested by Figure 1 that indicates a sharp increase of nearly four-fold in Tanzania's imports from 2002 to 2009. However, note that a large share of the increase occurs prior to the customs union implementation in 2005 - probably in anticipation of the event. This anticipatory effect is not captured in the regression estimation. This effect is shown in results provided in Table 6.

Table 3 shows the effect of the customs union on Uganda's intra-EAC trade flows. Again looking at the key variable of interest, CUA-intra, both results from column one and two suggest the customs union has had a significant positive effect on Uganda's exports to the EAC. The coefficients are large, positive $(0.964$, and 0.953$)$ and significant at $5 \%$ level. Hence the intra-bloc effect is given by $[100 *(e 0.953-1)=159 \%]$. This suggests an intra-bloc trade level of $159 \%$ above predicted. Figure 2 shows a six-fold increase from $\$ 65$ million to over $\$ 330$ million, which supports the findings in Table 3. Column three and four estimation results suggest the customs union has not had a significant effect on Uganda's the intra-bloc imports.

Table 2. Effect of the EAC Customs Union on Tanzania's Intra EAC Trade

\begin{tabular}{|c|c|c|c|c|}
\hline & $\begin{array}{l}\text { Model } 1^{\mathrm{A}} \\
\text { (Equation 3) }\end{array}$ & $\begin{array}{l}\text { Model } 1^{\mathrm{B}} \\
\text { (Equation 4) }\end{array}$ & $\begin{array}{l}\text { Model 2 } \\
\text { (Equation 5) }\end{array}$ & $\begin{array}{l}\text { Model } 2^{\mathrm{B}} \\
\text { (Equation 6) }\end{array}$ \\
\hline & $\begin{array}{l}\text { Dependent } \\
\text { variable: } \\
\text { ln(imports) }\end{array}$ & $\begin{array}{l}\text { Dependent } \\
\text { variable: } \\
\ln \text { (imports) }\end{array}$ & $\begin{array}{l}\text { Dependent } \\
\text { variable: } \\
\ln \text { (exports) }\end{array}$ & $\begin{array}{l}\text { Dependent } \\
\text { variable: } \\
\ln \text { (exports) }\end{array}$ \\
\hline Explanatory variables & Coefficient & Coefficient & Coefficient & Coefficient \\
\hline Contiguity & $\begin{array}{l}-4.720 \\
(* * *-6.52)\end{array}$ & $\begin{array}{l}-4.701 \\
(* * *-6.47)\end{array}$ & $\begin{array}{l}-1.935 \\
(-1.04) \\
\end{array}$ & $\begin{array}{l}-2.049 \\
(-1.09)\end{array}$ \\
\hline $\begin{array}{l}\text { Common language - } \\
\text { ethnology }\end{array}$ & $\begin{array}{l}0.168 \\
(0.08) \\
\end{array}$ & -- & $\begin{array}{l}4.795 \\
(* * * 3.05)\end{array}$ & $\begin{array}{l}4.845 \\
(* * * 3.07)\end{array}$ \\
\hline Distance & $\begin{array}{l}0.170 \\
(0.34)\end{array}$ & $\begin{array}{l}0.185 \\
(0.37)\end{array}$ & $\begin{array}{l}0.960 \\
(1.06) \\
\end{array}$ & $\begin{array}{l}0.998 \\
(1.10) \\
\end{array}$ \\
\hline Population - importer & $\begin{array}{l}-0.287 \\
(-0.36) \\
\end{array}$ & $\begin{array}{l}-0.288 \\
(-0.36)\end{array}$ & $\begin{array}{l}-4.337 \\
(-0.93) \\
\end{array}$ & -- \\
\hline Population - exporter & $\begin{array}{l}0.404 \\
(0.09)\end{array}$ & -- & $\begin{array}{l}0.631 \\
(0.79)\end{array}$ & $\begin{array}{l}0.498 \\
(0.62)\end{array}$ \\
\hline Real GDP - importer & $\begin{array}{l}-0.209 \\
(-0.48) \\
\end{array}$ & $\begin{array}{l}-0.202 \\
(-0.46) \\
\end{array}$ & $\begin{array}{l}1.727 \\
(0.86)\end{array}$ & -- \\
\hline Real GDP - exporter & $\begin{array}{l}0.038 \\
(0.02)\end{array}$ & -- & $\begin{array}{l}-0.793 \\
(*-1.79) \\
\end{array}$ & $\begin{array}{l}-0.655 \\
(-1.46) \\
\end{array}$ \\
\hline Real exchange rate & $\begin{array}{l}0.090 \\
(* 1.74)\end{array}$ & $\begin{array}{l}0.082 \\
(1.56)\end{array}$ & $\begin{array}{l}-0.006 \\
(-0.11)\end{array}$ & $\begin{array}{l}-0.011 \\
(-0.20)\end{array}$ \\
\hline CUA_intra & $\begin{array}{l}-0.246 \\
(-0.75) \\
\end{array}$ & $\begin{array}{l}-0.216 \\
(-0.66) \\
\end{array}$ & $\begin{array}{l}0.221 \\
(0.64)\end{array}$ & $\begin{array}{l}0.281 \\
(0.81)\end{array}$ \\
\hline Constant & $\begin{array}{l}0.918 \\
(0.03)\end{array}$ & $\begin{array}{l}2.715 \\
(0.20)\end{array}$ & $\begin{array}{l}-16.651 \\
(-0.56)\end{array}$ & $\begin{array}{l}5.077 \\
(0.54)\end{array}$ \\
\hline
\end{tabular}

Notes: Model 1 estimates effect on Tanzania's exports to the EAC countries (i.e. imports from Tanzania); Model 2 estimates effect on Tanzania's imports from EAC countries (i.e. exports to Tanzania). ${ }^{\text {A) }}$ Includes country fixed effects only; ${ }^{\text {B) }}$ includes both country and time fixed effects. The t-statistics are provided in brackets; $(* * *),(* *),(*)$ indicates the coefficients are statistically significant at the $1 \%, 5 \%$, or $10 \%$ level. (--) indicates variable dropped. The analysis uses only exports (imports) by one country to (from) 70 trading partners with time fixed effects controlling for change in this variable in time $t$ which means this variable cannot be estimated. 
Table 3. Effect of the EAC Customs Union on Uganda's Intra EAC Trade

\begin{tabular}{lllll}
\hline & $\begin{array}{l}\text { Model } 1^{\mathrm{A}} \\
(\text { Equation 3) }\end{array}$ & $\begin{array}{l}\text { Model 1 } \\
\text { (Equation 4) }\end{array}$ & $\begin{array}{l}\text { Model 2 } \\
\text { (Equation 5) }\end{array}$ & $\begin{array}{l}\text { Model 2 } \\
\text { (Equation 6) }\end{array}$ \\
\hline & $\begin{array}{l}\text { Dependent } \\
\text { variable: } \\
\ln (\text { imports) }\end{array}$ & $\begin{array}{l}\text { Dependent } \\
\text { variable: } \\
\ln (\text { imports) }\end{array}$ & $\begin{array}{l}\text { Dependent } \\
\text { variable: } \\
\ln (\text { exports) }\end{array}$ & $\begin{array}{l}\text { Dependent } \\
\text { variable: } \\
\ln (\text { exports) }\end{array}$ \\
\hline Explanatory variables & Coefficient & Coefficient & Coefficient & Coefficient \\
\hline Contiguity & -6.930 & -6.838 & 11.838 & 11.784 \\
& $(* * *-3.02)$ & $(* * *-2.96)$ & $(* * * 9.36)$ & $(* * * 9.29)$ \\
\hline Common language - & 6.267 & 6.028 & -11.182 & -11.067 \\
ethnology & $(* * * 3.75)$ & $(* * * 3.69)$ & $(* * *-4.98)$ & $(* * *-4.91)$ \\
\hline Distance & 1.411 & 1.379 & 2.922 & 2.914 \\
& $(1.24)$ & $(1.20)$ & $(* * * 4.13)$ & $(* * * 4.11)$ \\
\hline Population - importer & -1.843 & -1.826 & 0.323 & -- \\
& $(*-1.78)$ & $(*-1.75)$ & $(0.09)$ & \\
\hline Population - exporter & -0.904 & -- & -2.531 & -2.519 \\
& $(-0.22)$ & & $(* * *-2.81)$ & $(* * *-2.78)$ \\
\hline Real GDP - importer & 0.500 & 0.524 & -0.118 & -- \\
& $(0.94)$ & $(0.97)$ & $(-0.07)$ & \\
\hline Real GDP - exporter & -0.005 & -- & -0.200 & -0.187 \\
& $(-0.00)$ & & $(-0.40)$ & $(-0.37)$ \\
\hline Real exchange rate & -0.002 & 0.003 & -0.022 & -0.021 \\
& $(-0.04)$ & $(0.05)$ & $(-0.36)$ & $(-0.35)$ \\
\hline CUA_intra & 0.964 & 0.953 & 0.053 & 0.052 \\
& $(* * 2.34)$ & $(* * 2.30)$ & $(0.14)$ & $(0.14)$ \\
\hline Constant & -12.948 & -16.063 & -2.229 & -4.132 \\
& $(-0.42)$ & $(-1.44)$ & $(-0.08)$ & $(-0.36)$ \\
\hline
\end{tabular}

Notes: Model 1 estimates effect on Uganda's exports to the EAC countries (i.e. Imports from Uganda); Model 2 estimates effect on Uganda's imports from EAC countries (i.e. exports to Uganda). ${ }^{\text {A) }}$ Includes country fixed effects only; ${ }^{\text {B) }}$ includes both country and time fixed effects. The t-statistics are provided in brackets; $\left({ }^{* *}\right),\left({ }^{*}\right),\left({ }^{*}\right)$ indicates the coefficients are statistically significant at the $1 \%, 5 \%$, or $10 \%$ level. $(--)$ indicates variable dropped. The analysis uses only exports (imports) by one country to (from) 70 trading partners with time fixed effects controlling for change in this variable in time $t$ which means this variable cannot be estimated.

Table 4 shows the effect of the customs union on Burundi's intra-EAC trade flows. Columns one and two estimation results suggest the customs union has not had a significant effect on this country's intra EAC exports. Columns three and four results also show there is no significant effect from the customs union on Burundi's intra EAC imports. Similarly, no effect is detected for Rwanda from Table 5 results. But note that these countries officially joined EAC only in 2007. 
Table 4. Effect of the EAC Customs Union on Burundi's Intra EAC Trade

\begin{tabular}{|c|c|c|c|c|}
\hline & $\begin{array}{l}\text { Model } 1^{\mathrm{A}} \\
\text { (Equation 3) }\end{array}$ & $\begin{array}{l}\text { Model } 1^{\mathrm{B}} \\
\text { (Equation 4) }\end{array}$ & $\begin{array}{l}\text { Model 2 } 2^{\mathrm{A}} \\
\text { (Equation 5) }\end{array}$ & $\begin{array}{l}\text { Model } 2^{\mathrm{B}} \\
\text { (Equation 6) }\end{array}$ \\
\hline & $\begin{array}{l}\text { Dependent } \\
\text { variable: } \\
\ln \text { (imports) }\end{array}$ & $\begin{array}{l}\text { Dependent } \\
\text { variable: } \\
\ln \text { (imports) }\end{array}$ & $\begin{array}{l}\text { Dependent } \\
\text { variable: } \\
\ln \text { (exports) }\end{array}$ & $\begin{array}{l}\text { Dependent } \\
\text { variable: } \\
\ln \text { (exports) }\end{array}$ \\
\hline Explanatory variables & Coefficient & Coefficient & Coefficient & Coefficient \\
\hline Contiguity & $\begin{array}{l}3.195 \\
(1.03) \\
\end{array}$ & $\begin{array}{l}1.622 \\
(0.29)\end{array}$ & $\begin{array}{l}-9.951 \\
(* * *-4.22)\end{array}$ & $\begin{array}{l}-9.793 \\
(* * *-4.05)\end{array}$ \\
\hline $\begin{array}{l}\text { Common language - } \\
\text { Ethnology }\end{array}$ & $\begin{array}{l}0.486 \\
(0.18) \\
\end{array}$ & $\begin{array}{l}0.752 \\
(0.17)\end{array}$ & $\begin{array}{l}4.894 \\
(* * * 2.74)\end{array}$ & $\begin{array}{l}4.629 \\
(* * 2.56)\end{array}$ \\
\hline Distance & $\begin{array}{l}0.095 \\
(0.05)\end{array}$ & $\begin{array}{l}-0.610 \\
(-0.31) \\
\end{array}$ & $\begin{array}{l}-2.125 \\
(* * *-3.54)\end{array}$ & $\begin{array}{l}-1.984 \\
(* * * 3.10)\end{array}$ \\
\hline Population - importer & $\begin{array}{l}0.889 \\
(0.65)\end{array}$ & $\begin{array}{l}0.944 \\
(0.67)\end{array}$ & $\begin{array}{l}-0.854 \\
(-0.29) \\
\end{array}$ & -- \\
\hline Population - exporter & $\begin{array}{l}-1.053 \\
(-0.29) \\
\end{array}$ & -- & $\begin{array}{l}1.129 \\
(0.93)\end{array}$ & $\begin{array}{l}0.847 \\
(0.67)\end{array}$ \\
\hline Real GDP - importer & $\begin{array}{l}-0.029 \\
(-0.04) \\
\end{array}$ & $\begin{array}{l}-0.167 \\
(-0.22)\end{array}$ & $\begin{array}{l}-0.400 \\
(-0.14) \\
\end{array}$ & -- \\
\hline Real GDP - exporter & $\begin{array}{l}0.442 \\
(0.13) \\
\end{array}$ & -- & $\begin{array}{l}-0.300 \\
(-0.60) \\
\end{array}$ & $\begin{array}{l}-0.256 \\
(-0.51) \\
\end{array}$ \\
\hline Real exchange rate & $\begin{array}{l}0.133 \\
(* * 1.98) \\
\end{array}$ & $\begin{array}{l}0.141 \\
(* 1.90) \\
\end{array}$ & $\begin{array}{l}-0.035 \\
(-0.71) \\
\end{array}$ & $\begin{array}{l}-0.044 \\
(-0.81) \\
\end{array}$ \\
\hline CUA_intra & $\begin{array}{l}-0.096 \\
(-0.21) \\
\end{array}$ & $\begin{array}{l}-0.084 \\
(-0.17) \\
\end{array}$ & $\begin{array}{l}-0.077 \\
(-.20) \\
\end{array}$ & $\begin{array}{l}0.005 \\
(0.01) \\
\end{array}$ \\
\hline Constant & $\begin{array}{l}-16.023 \\
(-0.25)\end{array}$ & $\begin{array}{l}-0.987 \\
(-0.05)\end{array}$ & $\begin{array}{l}25.530 \\
(0.49)\end{array}$ & $\begin{array}{l}14.644 \\
(1.60)\end{array}$ \\
\hline
\end{tabular}

Notes: Model 1 estimates effect on Burundi's exports to the EAC countries (i.e. imports from Burundi); Model 2 estimates effect on Burundi's imports from EAC countries (i.e. exports to Burundi). ${ }^{\text {A) }}$ Includes country fixed effects only; ${ }^{\text {B) }}$ Includes both country and time fixed effects. The t-statistics are provided in brackets; $(* * *),(* *),(*)$ indicates the coefficients are statistically significant at the $1 \%, 5 \%$, or $10 \%$ level. (--) indicates variable dropped. The analysis uses only exports (imports) by one country to (from) 70 trading partners with time fixed effects controlling for change in this variable in time $t$ which means this variable cannot be estimated. 
Table 5. Effect of the EAC Customs Union on Rwanda's Intra EAC Trade

\begin{tabular}{lllll}
\hline & $\begin{array}{l}\text { Model } 1^{\mathrm{A}} \\
(\text { Equation 3) }\end{array}$ & $\begin{array}{l}\text { Model 1 } \\
\text { (Equation 4) }\end{array}$ & $\begin{array}{l}\text { Model 2 } \\
\text { (Equation 5) }\end{array}$ & $\begin{array}{l}\text { Model 2 } \\
\text { (Equation 6) }\end{array}$ \\
\hline & $\begin{array}{l}\text { Dependent } \\
\text { variable: } \\
\ln (\text { imports) }\end{array}$ & $\begin{array}{l}\text { Dependent } \\
\text { variable: } \\
\ln (\text { imports) }\end{array}$ & $\begin{array}{l}\text { Dependent } \\
\text { variable: } \\
\ln (\text { exports) }\end{array}$ & $\begin{array}{l}\text { Dependent } \\
\text { variable: } \\
\ln (\text { exports) }\end{array}$ \\
\hline Explanatory variables & Coefficient & Coefficient & Coefficient & Coefficient \\
\hline Contiguity & 1.308 & 3.165 & 0.501 & 0.523 \\
& $(0.54)$ & $(1.27)$ & $(0.17)$ & $(0.17)$ \\
\hline Common language & 4.419 & -0.606 & 1.811 & 1.630 \\
- ethnology & $(1.24)$ & $(-0.16)$ & $(0.63)$ & $(0.57)$ \\
\hline Distance & 1.041 & -1.366 & -0.991 & -1.098 \\
& $(0.49)$ & $(-0.94)$ & $(-0.77)$ & $(-0.85)$ \\
\hline Population - importer & -0.413 & -0.336 & -0.300 & -- \\
& $(-0.24)$ & $(-0.19)$ & $(-0.32)$ & \\
\hline Population - exporter & 0.644 & -- & 0.151 & 0.164 \\
& $(0.49)$ & & $(0.13)$ & $(0.14)$ \\
\hline Real GDP - importer & 0.124 & 0.127 & -0.292 & -- \\
& $(0.15)$ & $(0.15)$ & $(-0.50)$ & \\
\hline Real GDP - exporter & -0.210 & - & -0.268 & -0.125 \\
& $(-0.25)$ & & $(-0.51)$ & $(-0.23)$ \\
\hline Real exchange rate & -0.007 & -0.007 & 0.022 & 0.041 \\
& $(-0.08)$ & $(-0.09)$ & $(0.37)$ & $(0.66)$ \\
\hline CUA_intra & -0.047 & -0.105 & 0.286 & 0.312 \\
& $(-0.09)$ & $(-0.20)$ & $(0.70)$ & $(0.75)$ \\
\hline Constant & -15.050 & 2.179 & 17.109 & 7.928 \\
& $(-0.92)$ & $(0.10)$ & $(* 1.65)$ & $(0.73)$ \\
\hline
\end{tabular}

Notes: Model 1 estimates effect on Rwanda's exports to the EAC countries (i.e. imports from Rwanda); Model 2 estimates effect on Rwanda's imports from EAC countries (i.e. exports to Rwanda). ${ }^{\text {A) }}$ Includes country fixed effects only; ${ }^{\text {B) }}$ Includes both country and time fixed effects. The t-statistics are provided in brackets; $(* * *),(* *),(*)$ indicates the coefficients are statistically significant at the $1 \%, 5 \%$, or $10 \%$ level. (--) indicates variable dropped. The analysis uses only exports (imports) by one country to (from) 70 trading partners with time fixed effects controlling for change in this variable in time $t$ which means this variable cannot be estimated.

The preceding analyses has attempted to capture the customs union effects using dummy variables constructed based on the date of implementation (the year 2005) for Kenya, Uganda and Tanzania and date of entry (year 2007) for Burundi and Rwanda. However, the customs union protocol was negotiated over a period of time before it was finally agreed upon. Therefore the agents in the market were aware of it and it would be reasonable to expect anticipatory market reaction in advance of the actual date of implementation.

To test for anticipation effects a dummy variable, L3-CUA-intra, is included in the analysis. This is similar to CUA-intra but lagged three years. This is used to capture the effect, if any, of the customs union from three years before implementation. The estimation results are shown in Table 6 . 
Table 6. Anticipatory Effects of the Customs union on Intra EAC Trade

\begin{tabular}{llll}
\hline Country & Exp. variable & (Imports from) Model $1^{\mathrm{B}}$ & ${\text { (Exports to) Model } 2^{\mathrm{B}}}^{\text {Kenya }}$ \\
\cline { 2 - 4 } & $\mathrm{L}_{3}$-CUA-intra & $0.618(* * 2.19)$ & $-0.395(-0.98)$ \\
\cline { 2 - 4 } Tanzania & CUA-intra & $-0.481(-1.55)$ & $0.992(* * 2.21)$ \\
\cline { 2 - 4 } & $\mathrm{L}_{3}$-CUA-intra & $-0.198(-0.53)$ & $0.961(* * 2.45)$ \\
\hline \multirow{2}{*}{ Uganda } & CUA-intra & $-0.089(-0.22)$ & $-0.340(-0.79)$ \\
\cline { 2 - 4 } & $\mathrm{L}_{3}$-CUA-intra & $-0.155(-0.35)$ & $0.309(0.66)$ \\
\hline \multirow{2}{*}{ Burundi } & CUA-intra & $1.049(* * 2.11)$ & $-0.153(-0.31)$ \\
\cline { 2 - 4 } & $\mathrm{L}_{3}$-CUA-intra & $-0.188(-0.39)$ & $0.491(1.28)$ \\
\hline \multirow{2}{*}{ Rwanda } & CUA-intra & $0.023(0.24)$ & $-0.259(-0.57)$ \\
\cline { 2 - 4 } & $\mathrm{L}_{3}$-CUA-intra & $1.171(* * 2.16)$ & $0.410(0.97)$ \\
\hline & CUA-intra & $-0.827(-1.32)$ & $0.044(0.09)$ \\
\hline
\end{tabular}

Note: Model $1^{\mathrm{B}}$ estimates the effect of customs union on imports from stated country (i.e. country exports) with both country and time fixed effects included. Model $2^{\mathrm{B}}$ estimates the effect on exports to the stated country (i.e. country imports) with both country and time fixed effects included. The t-statistics are provided in brackets. $(* * *),(* *),(*)$ indicates the coefficients are statistically significant at the $1 \%, 5 \%$, or $10 \%$ level. CUA-intra is constructed using date of implementation (2005), while $L_{3}-C U A$-intra is $C U A$-intra lagged three years.

Only the coefficients and t-values on the lagged L3-CUA-intra and contemporaneous CUA-intra customs union dummies for the estimation specification that includes both country and time fixed effects (1B and $2 \mathrm{~B})$ are provided. The results indicate a positive customs union effect on Kenya's exports before the actual implementation date and no significant impact on implementation. The coefficient on L3-CUA-intra is 0.618 ( $85.5 \%$ increase) and significant but the coefficient on CUA-intra is not significant. This suggests there was some significant anticipation reaction by Kenyan exporters. But because the Kenyan exports to EAC countries did not all achieve duty free status immediately on implementation of the customs union, this may explain why the actual implementation had no further significant impact. These results tie better with Figure 2 which shows a sharp increase in Kenyan exports around 2002. Regarding imports, there is no anticipatory effect but the actual implementation had significant effect on Kenyan imports from the EAC. These results are similar to that obtained earlier in Table 1. Thus combining these results with that of Table 1, it seems to suggest that Kenyan exporters were able to and reacted earlier to the expected customs union, while the other EAC countries exporters were only able to tap the Kenya market after the actual removal of the tariffs upon implementation.

Turning to Tanzania, the results suggest there was no anticipatory effect on Tanzanian exports. The results are therefore similar to that already discussed in Table 2. However the results on imports differ from that in Table 2 . The coefficient on L3-CUA-intra is (0.961) positive and significant, suggesting an effect of about $161 \%$ increase predating the actual implementation date. These results are more consistent with Figure 1 which shows a sharp increase in Tanzania's imports from 2002. Uganda and Burundi's results are similar to earlier results in Table 3 and 4. Uganda's exports have only increased after the actual removal of internal tariffs on her goods. Rwanda's exports to the EAC also show some significant anticipatory increase of about $223 \%$. However for both Rwanda and Burundi it is worth noting we have very few post entry data. Overall the results suggest some anticipatory effects on exports from Kenya and Rwanda, and imports into Tanzania. The full effect of the customs union is unlikely to have been captured by the anticipatory effects and the contemporaneous effects during the implementation period because some internal tariffs were only eliminated gradually over the transition period. Due to limited post transition period (2009) data we are not able to capture the evolution of these effects after complete implementation of tariff elimination in this analysis.

\section{Conclusion}

The study uses a variety of specifications to estimate the effects of the EAC custom union agreement on intra EAC trade. The time frame covers the years $1996-2009$ for seventy potential trading partners for the EAC countries from Africa, Western Europe, Eastern Europe, North and South America. The paper assesses how the implementation of the customs union over the transition period has affected the intra EAC trade levels for each of the five member countries. The majority of the existing studies estimate an average treatment effect across an FTA membership. However it is not necessarily true that membership in an FTA produces the same effect on each member country. Some countries may be better placed to achieve a higher than average increase from free trade. Such differences may be large enough to warrant specific country analysis. This is relevant to the EAC given that one of the main concerns that led to the demise of the original EAC in 1977, in addition to ideological differences at the time, was the concern that some members were benefiting disproportionately. 
In this study the effects of the customs union agreement on the intra EAC trade flows for member country is estimated. This is done in a framework that controls for country and time fixed effects. The customs union was signed in 2004, and gradually implemented from 2005 to 2009. However its trade effects on individual member countries have not been empirically estimated. The results, as expected, suggest that the EAC customs union has had different effects on its members' exports and imports. The customs union has increased Kenya's intra EAC imports by about 104 percent to 170 percent. This implies the EAC member countries have taken advantage of the immediate duty free status of goods entering Kenya. However the custom union has not had a significant impact on imports by other EAC countries, except for Tanzania. The results indicate an anticipatory increase predating the implementation of the customs union of about 161 percent.

In terms of exports, Uganda's exports to the EAC bloc have increased by about 159 percent to 185 percent. The implementation of the custom union has not had a significant contemporaneous effect on Kenya's exports. However there is an anticipatory increase in Kenyan exports to EAC of about $86 \%$. The reason may be due to the fact that some of Kenya's exports to the EAC bloc were not granted immediate duty free status. Rather the tariff rate was reduced gradually to zero over a 5 year period starting 2005. Due to data availability, the analysis has been limited to 2009 and earlier. This captures only the five year transition period. Noting that internal tariffs were not completely removed till the end of the analysis period, the results provided here possibly do not capture the full effects of the customs union, but most likely understates it. In summary Kenya, Uganda and Rwanda have seen a significant increase in intra EAC exports. But only Kenya and Tanzania have seen a significant increase in their intra EAC imports.

\section{References}

Bair, S. L., \& Bergstrand, J. H. (2007). Do free trade agreements actually increase member's international trade? Journal of International Economics, 71, 72-95.

Carrère, C. (2006). Revisiting the effects of regional trade agreements on trade flows with proper specification of the gravity model. European Economic Review, 50, 223-247. http://dx.doi.org/10.1016/j.euroecorev.2004.06.001

Clausing, K. (2001). The trade creation and trade diversion in the Canada-United States free trade agreement. Canadian Journal of Economics, 34, 677-696. http://dx.doi.org/10.1111/0008-4085.00094

Darku, A. B. (2009). The gravity model and the test for the regional integration effect: the case of Tanzania. Journal of Developing Areas, 43(1), 25-44. http://dx.doi.org/10.1353/jda.0.0040

Egger, P. (2000). A note on the proper econometric specification of the gravity equation. Economics Letters, 66, 25-31. http://dx.doi.org/10.1016/S0165-1765(99)00183-4

Egger, P., \& Pfaffermayr, M. (2003). The proper panel econometric specification of the gravity equation: a three-way model with bilateral interaction effects. Empirical Economics, 28, 571-580. http://dx.doi.org/10.1007/s001810200146

Frankel, J. (1997). Regional Trade Blocs in the World Economic System. Washington D. C., Institute for International Economics.

Glick R., \& Rose A. K. (2002). Does a currency union affect trade? the time series evidence. European Economic Review, 46(6), 1125-1151. http://dx.doi.org/10.1016/S0014-2921(01)00202-1

Goldstein A., \& Ndungu, S. N. (2001). Regional integration experience in the Eastern African Region. OECD Development Centre, Working Paper No. 171.

Magee, C. (2003). Endogenous preferential trade agreements: an empirical analysis. Contributions to Economic Analysis \& Policy, 2(1), Article 15.

Magee, C. S. P. (2008). New measures of trade creation and trade diversion. Journal of International Economics, 75, 49-362. http://dx.doi.org/10.1016/j.jinteco.2008.03.006

Musila, W. J. (2005). The intensity of trade creation and trade diversion in COMESA, ECCAS and ECOWAS: a comparative analysis. Journal of African Economies, 14(1), 117-141. http://dx.doi.org/10.1093/jae/ejh039

Rose, J., \& Van Wincoop, E. (2001). National money as a barrier to international trade: the real case for currency union. American Economic Review: Papers and Proceedings, 91(2), 386-390. http://dx.doi.org/10.1257/aer.91.2.386

Sawkut, R. (2006). COMESA trade potential: a gravity approach. Applied Economics Letters, 13(14), 947-951. http://dx.doi.org/10.1080/13504850500426061 
Appendix I: List of Countries Included in the Analysis.

\begin{tabular}{|c|l|c|l|c|l|l|l|}
\hline & Country & & Country & & Country & & Country \\
\hline 1 & Austria & 19 & Norway & 37 & South Africa & 55 & Hungary \\
\hline 2 & Finland & 20 & Singapore & 38 & Sudan & 56 & Poland \\
\hline 3 & France & 21 & Sweden & 39 & Swaziland & 57 & Romania \\
\hline 4 & Germany & 22 & Switzerland & 40 & $*$ Tanzania & 58 & Turkey \\
\hline 5 & Greece & 23 & United Kingdom & 41 & *Uganda & 59 & Russia \\
\hline 6 & Ireland & 24 & United States & 42 & Zambia & 60 & Ukraine \\
\hline 7 & Italy & 25 & *Burundi & 43 & Zimbabwe & 61 & Bahrain \\
\hline 8 & Netherlands & 26 & Congo, D. R. & 44 & Bangladesh & 62 & Egypt \\
\hline 9 & Portugal & 27 & Congo, Rep. of & 45 & China P. R.: Mainland & 63 & Iran \\
\hline 10 & Spain & 28 & Côte d'Ivoire & 46 & India & 64 & Jordan \\
\hline 11 & Australia & 29 & Djibouti & 47 & Indonesia & 65 & Kuwait \\
\hline 12 & Canada & 30 & Ethiopia & 48 & Malaysia & 66 & Oman \\
\hline 13 & China,P.R.: Hong Kong & 31 & *Kenya & 49 & Pakistan & 67 & Qatar \\
\hline 14 & Denmark & 32 & Malawi & 50 & Philippines & 68 & Saudi Arabia \\
\hline 15 & Israel & 33 & Mauritius & 51 & Sri Lanka & 69 & UAE \\
\hline 16 & Japan & Mozambique & 52 & Thailand & 70 & Argentina \\
\hline 17 & Korea & Nigeria & 53 & Bulgaria & 71 & Brazil \\
\hline 18 & New Zealand & *Rwanda & 54 & Czech Republic & & \\
\hline
\end{tabular}

Note: * Indicates EAC member Country. 